\title{
Application of electrochemical aptasensors in detection of cancer biomarkers
}

\author{
Masoud Negahdary ${ }^{1, *}$, Ali Moradi ${ }^{2}$, Hossein Heli ${ }^{1, *}$
}

${ }^{1}$ Nanomedicine and Nanobiology

Research Center, Shiraz University of

Medical Sciences, Shiraz, Iran

${ }^{2}$ Department of Biochemistry, Shahid Sadoughi University of Medical Sciences, Yazd, Iran

\section{Correspondence}

Masoud Negahdary, Nanomedicine and Nanobiology Research Center, Shiraz University of Medical Sciences, Shiraz, Iran

Email: masoudnegahdary@ssu.ac.ir

Correspondence

Hossein Heli, Nanomedicine and Nanobiology Research Center, Shiraz University of Medical Sciences, Shiraz, Iran

Email: heli@sums.ac.ir

\section{History}

- Received: Apr 14, 2019

- Accepted: Jun 17, 2019

- Published: Jul 28, 2019

DOI :

https://doi.org/10.15419/bmrat.v6i7.558

\section{Check for updates}

\section{Copyright}

(c) Biomedpress. This is an openaccess article distributed under the terms of the Creative Commons Attribution 4.0 International license.

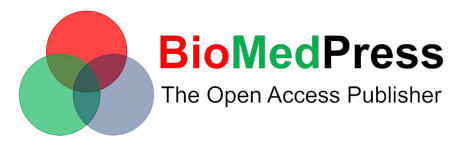

\begin{abstract}
Today, the late diagnosis of cancers is a big challenge, and using novel diagnostic techniques will provide essential, faster and more accurate treatments. Unfortunately, existing common and traditional diagnostic methods have not been helpful completely and most cancers are diagnosed too late. Recently, researchers have found new diagnostic methods against cancers by aptasensors; these sensory systems can detect involved biomarkers in various cancers so that the research in this field is continued strictly. Aptasensors can detect cancer markers in small quantities and high selectivity; moreover, other advantages of cancer aptasensors such as optimized time and cost saving can be considered. In addition, the aptasensors have been used in the diagnosis of the effective and related factors in cancer therapy follow-up. Here, the most researches about cancer aptasensors and other involved markers were collected, reviewed and described.

Key words: Aptasensor, Electrochemical detection, Aptamer, Cancer, Biomarker
\end{abstract}

\section{INTRODUCTION}

Changes in the traditions of lifestyle have led to the transform the dietary patterns, including increased intake saturated fat and reduced the fruits and vegetables, air pollutant, stress, different waves, etc. These major elements have led to the increased prevalence of non-communicable diseases such as cardiovascular disease, cancer, diabetes, etc ${ }^{1-6}$. The sudden and uncontrolled growth of cells in a part of the body caused by genetics and inheritance, some viruses, environmental hazards (smoking, ionizing radiation, and chemicals) or pattern and lifestyle in terms of diet, the reduced time of exercise and increased stress are considered as the related risk factors of various cancers $^{7-11}$. Annually, millions of cancer cases are found in the world. At the early stages, the diagnosis of cancerous cells are limited and complicated ${ }^{12-15}$; One of the main problems in the cancer treatment is the lack of a suitable method for early diagnosis ${ }^{16,17}$. The big challenge associated with various cancers is the delayed diagnosis and the occurrence of metastasis ${ }^{18,19}$. However, the detection of cancers at the early stages is usually impossible with existing methods ${ }^{20,21}$. Delay in the treatment will lead to metastasis ${ }^{20,21}$. Along with the late diagnosis, cancer involves other organs and tissues leading to difficult treatment process ${ }^{20,21}$. One of the main goals of the researches is finding biomarkers to detect cancer at early stages ${ }^{22-24}$. Generally, biomarkers refer to a group of measurable indicators of some biological conditions ${ }^{25,26}$. Biomark- ers are often evaluated for the study of natural biological processes, the diagnosis of pathogenic processes or the response to a specific treatment. In recent years, special biomarkers have been used extensively to identify various diseases. Non-invasive, sensitive and cost-effective measurement, stability in the samples, specified diagnosis, early identification before the onset of symptoms, are main characteristics that can be desirable for a biomarker ${ }^{27,28}$. Over the past three decades, the use of synthetic DNA or RNA single-stranded oligonucleotides (aptamers) was expanded in various fields of biology and medicine in through different ways ${ }^{29-31}$. Aptamers can capture their molecular targets with high affinity and specificity. These properties are related to the ability of this category of biological molecules to interact with other molecules by refolding and conformational changes ${ }^{32,33}$. Aptasensors are kinds of biosensors that aptamers (DNA or RNA oligonucleotide sequences in a single strand status) act as the biorecognition element in their structure ${ }^{34,35}$. Given that the used aptamers in aptasensors are synthetic, the affinity and specificity of aptasensors towards the analytes can be controlled and enhanced ${ }^{36,37}$. Aptasensors can detect analytes in very small amounts where these minimalistic amounts are not detectable with most of the other existing methods ${ }^{38,39}$; in addition, the low cost for designing the aptasensors compared to other cancer diagnostics methods should be considered as one of the economic savings ${ }^{40,41}$. Other considerable advantages of aptasensors compared to other available 
diagnostic techniques are low detection time and fast detection process $34,36,39,40,42$. In this review, the applications of aptasensors in order to the diagnosis of cancer biomarkers were collected and reviewed from related researches.

\section{ELECTROCHEMICAL APTASENSORS}

Electrochemical biosensors are attended by numerous advantages, including simplicity, low cost, high selectivity and high sensitivity. Hence, these sensors have become powerful tools in various biomedical fields, especially the diagnosis of diseases. Electrochemical sensors are typically classified as amperometric sensors, potentiometric sensors, and impedance sensors. Electrochemical sensors consist of three main components, including biorecognition element, transducer and detector. In electrochemical aptasensors, the biorecognition element is aptamer. This biorecognition element is usually chosen to have the most affinity against analyte. The principle of diagnosis in electrochemical aptasensors is based on redox behavior. In the absence of an analyte in the environment, the redox molecules are placed at a specified distance near the aptamer, which will lead to recording an electrochemical current. In the presence of analyte molecules in the environment, due to the specific affinity between aptamer and analyte, analyte molecules are captured and absorbed by aptamer molecules, which lead to the placement of redox molecules at different distances; this approach creates and records a different electrochemical current ${ }^{43-46}$. By evaluating and comparing recorded electrochemical currents, it is possible to detect analytes quantitatively and in very small amounts by these electrochemical aptasensors.

\section{APTASENSORS FOR DETECTION OF VASCULAR ENDOTHELIAL GROWTH FACTOR (VEGF)}

In a research, Qureshi et al. tried to design an aptasensor in order to detect the VEGF in human serum ${ }^{47}$. VEGF as a signaling angiogenesis protein is related to some cancers; this research tried to use the dielectric measurements between aptamer and surface of the gold electrode in the absent/presence of VEGF. They offered an early and sensitive diagnosis method for VEGF in the range of 0.5 to $2 \mathrm{ng} \mathrm{mL}^{-1}$. In another research, designing an electrochemical aptasensor for detection the human mucin-1 (MUC1) and VEGF tumor markers were investigated by Zhao et al. ${ }^{48}$. They used of a three-electrode system whereas the working electrode was gold and the redox marker was ferro/ferricyanide $\left[\mathrm{Fe}(\mathrm{CN})_{6}{ }^{3-/ 4-}\right]$. The results of this study showed that this aptasensor was able to detect MUC1 and VEGF tumor markers up to $20 \mathrm{nM}$ (as the highest response). Cho et al. designed an aptasensor for early detection of VEGF $165^{49}$. The detection range of this experimental work was in a linear range from $25 \mathrm{pg} \mathrm{mL}^{-1}$ to $25 \mu \mathrm{g} \mathrm{mL}^{-1}$. In this work, the gold nanoparticles were used in order to improve the metal fluorophore interactions; the authors compared all achieved experimental results with enzyme-linked immunosorbent assay (ELISA) and this comparison confirmed the successful design of VEGF165 aptasensor. Amouzadeh Tabrizi et al. tried to design an electrochemical aptasensor in order to detect of VEGF165 tumor marker (10.0 to $300.0 \mathrm{pg} \mathrm{mL}^{-1}$ ) in the serum of lung cancer patients ${ }^{50}$. In their electrochemical measurements, several screen-printed electrodes (SPE) were used and main applied electrochemical detection techniques were cyclic voltammetry (CV) and electrochemical impedance spectroscopy (EIS) in an electrolyte containing $\left[\mathrm{Fe}(\mathrm{CN})_{6}{ }^{3-/ 4-}\right]$ as redox marker. Another aptasensor was designed to detection the VEGF ( 0 to $200 \mathrm{nM}$ ) based on surface plasmon resonance $(\mathrm{SPR})^{51}$.

\section{APTASENSORS FOR DETECTION THE PROSTATE-SPECIFIC ANTIGEN (PSA)}

PSA is considered as the major prostate cancer marker within the blood samples of patients; In a research Jolly et al. tried to design an aptasensor for PSA ${ }^{52}$; their analyses were determined based on the EIS method. The low detection ability of the analytes is a very important aim in all aptasensors and diagnostic methods; The PSA was detected in the range lower than $1 \mathrm{ng} \mathrm{mL} \mathrm{m}^{-1}$ in the mentioned work. In another research, the PSA detection was followed through a nanoaptasensor where the gold nanoparticles were encapsulated by graphitized mesoporous carbon $^{53}$. In this research, the electrochemical detection technique was differential pulse voltammetric (DPV) and this aptasensor could detect PSA in the patient's serum in the range of 0.25 to $200 \mathrm{ng} \mathrm{mL}^{-1}$. Designing an electrochemical aptasensor against PSA antigen using goldnanospears was followed by Rahi et al. ${ }^{54}$. They tried to detect PSA in the range of 0.125 to $200 \mathrm{ng} \mathrm{mL}^{-1}$ and the limit of detection (LOD) in their research was about $50 \mathrm{pg} \mathrm{mL}^{-1}$. In the mentioned research, a 32 mer thiolated aptamer ( $\left.5^{\prime}-\mathrm{SH}\right)$ was used in order to find optimized binding surface against the analyte. In their work, the methylene blue (MB) was used as the redox marker and all electrochemical measurements were based on CV and DPV 
techniques. Designing an electrochemical PSA aptasensor was followed using the carboxylic acid functionalized by carbon nanotubes $(\mathrm{CNTs}(\mathrm{COOH}))$, chitosan (Chit), carbon nanotubes-chitosan (CNTs-Chit and $\mathrm{CNTs}(\mathrm{COOH})-\mathrm{Chit})^{55}$. Here, all electrochemical studies were performed through CV, DPV, and EIS while the LOD for this aptasensor was $0.75 \mathrm{ng}$ $\mathrm{mL}^{-1}$. Another PSA aptasensor designing was followed based on chemiluminescence ${ }^{56}$; in this research, the PSA was detected in the range of 1.9 to 125 ng $\mathrm{mL}^{-1}$.

\section{APTASENSORS FOR DETECTION THE BREAST CANCER MCF-7 CELLS}

In a research, the breast cancer diagnosis was followed by Cai et al. ${ }^{57}$; they designed an aptasensor that was able to detect breast cancer MCF-7 cells in the range of 0 to 500 cells $\mathrm{mL}^{-1}$. Electrochemical results were obtained via chronocoulometry (CC), EIS and CV while the redox marker was $\left[\mathrm{Fe}(\mathrm{CN})_{6}{ }^{3-/ 4-}\right]$. In another research, Chang et al. offered an aptasensor in order to detect of the MCF-7 cells ${ }^{58}$. The detection plan was based on the leaky surface acoustic wave (LSAW- 100 $\mathrm{MHz}$ ) aptasensor array. This aptasensor could detect the MCF-7 cells in the range of $1 \times 10^{2}$ cells $\mathrm{mL}^{-1}$ to $1 \times 10^{7}$ cells $\mathrm{mL}^{-1}$; while the LOD was about 32 cells $\mathrm{mL}^{-1}$. Choosing a specific aptamer against analytes is very important in all aptasensors ${ }^{59}$. In the mentioned research, the authors used of a specific MUC1 aptamer in order to detect of the MCF-7 cells; in Figure 1 , by using the specific aptamer, the mentioned aptasensor was able to detect the MCF-7 cells while when the random DNA was used, the aptasensor did not work properly.

In a research, a fluorescent aptasensor was designed to detect the MCF-7 cells ${ }^{60}$. Cai et al. used fluorescence analysis as the main detection method and this aptasensor was able to detect the MCF-7 cells in the range of 500 to $5.0 \times 10^{5}$ cells $\mathrm{mL}^{-1}$ while LOD was 70 cells $\mathrm{mL}^{-1}$. In another research, a graphene oxide (GO) based aptasensor was designed that could detect the MCF-7 cells ( 180 to $8 \times 10^{7}$ cells $\mathrm{mL}^{-1}$ ), HL-60 (210 to $7 \times 10^{7}$ cells $\mathrm{mL}^{-1}$ ), and K562 (200 to $7 \times 10^{7}$ cells $\mathrm{mL}^{-1}$ ) cancer cells ${ }^{61}$. In this aptasensor, the mesoporous silica nanoparticles (MSNs) were used and all analysis were followed through visual fluorescence measurements. Li et al. introduced an aptasensor to detect the MCF-7 cells while the gold nanorods were used as a signal amplifier; the detection range was $10^{2}$ to $10^{5}$ cells $\mathrm{mL}^{-1}$ and LOD was calculated as 100 cells $\mathrm{mL}^{-162}$. The MUC1 aptamerfunctionalized gold nanorods applied in mentioned aptasensor and the all obtained results were analyzed through the localized surface plasmon resonance (LSPR) spectra. A colorimetric nanoaptasensor was designed using the aggregation of gold nanoparticles; after investigation of the absorption spectra, it applied to detect the MCF-7 cells in the range of 10 to $10^{5}$ cells $^{63}$. In a research, the MCF-7 cells were determined (100 to $5.0 \times 10^{7}$ cells $\mathrm{mL}^{-1}$ ) via an electrochemical aptasensor that used of the GO/Au composites and porous PtFe alloy as the signal amplifier ${ }^{64}$. The LOD for this aptasensor was reported as 38 cell $\mathrm{mL}^{-1}$. A fluorescent aptasensor was introduced by Li et al. that was based on the mesoporous carbon nanospheres ${ }^{65}$. This aptasensor presented a special way in order to detect the of MUC1 tumor marker molecules $\left(0.110 .6 \mu \mathrm{mol} \mathrm{L}^{-1}\right)$ and MCF-7 cells $\left(10^{4}\right.$. $2 \times 10^{6}$ cells $\left.\mathrm{mL}^{-1}\right)$. A photoelectrochemical aptasensor was designed to detect the MCF-7 cells ${ }^{66}$. This aptasensor could detect the MCF-7 cells at the range of $1 \times 10^{3}$ to $1 \times 10^{5}$ cells $\mathrm{mL}^{-1}$.

\section{APTASENSORS FOR DETECTION THE RAMOS CELLS}

An electrochemiluminescence aptasensor was developed to detect the Ramos cells (CRL-1596, B-cell, human Burkitt's lymphoma) via application of the $\mathrm{Au}$ and silica nanoparticles and magnetic beads ${ }^{67}$. This aptasensor could detect the Ramos cells in the linear range from 100 to 2000 cells $\mathrm{mL}^{-1}$. A nanoaptasensor (aptamer-nanoparticle strip biosensor) was designed by Liu et al. due to detection of the Ramos cells in the human blood samples ${ }^{68}$. The LOD for this aptasensor was about 800 Ramos cells.

\section{APTASENSORS FOR DETECTION THE TUMOR NECROSIS FACTOR- $\alpha$ (TNF- $\alpha$ )}

TNF- $\alpha$ is an anticancer agent used in cancer therapy through isolated limb perfusion and prevention amputation of the limb ${ }^{69}$. Experimental design of an aptasensor in order to detect the TNF- $\alpha$ was investigated by Liu et al. ${ }^{70}$. This research is one of the related tries to detect the biomaterials that have a role in cancer therapy. The performance mechanism of this aptasensor is shown in Figure 2.

In this research, the MB was used as redox marker in all electrochemical analyses. The MB molecules were attached to 5'end of RNA aptamer. All electrochemical measurements were performed through square wave voltammetry (SWV) and the LOD was $10 \mathrm{ng}$ $\mathrm{mL}^{-1}$ for TNF- $\alpha$. another research showed a try in designing an aptasensor for detecting the TNF- $\alpha$ at 

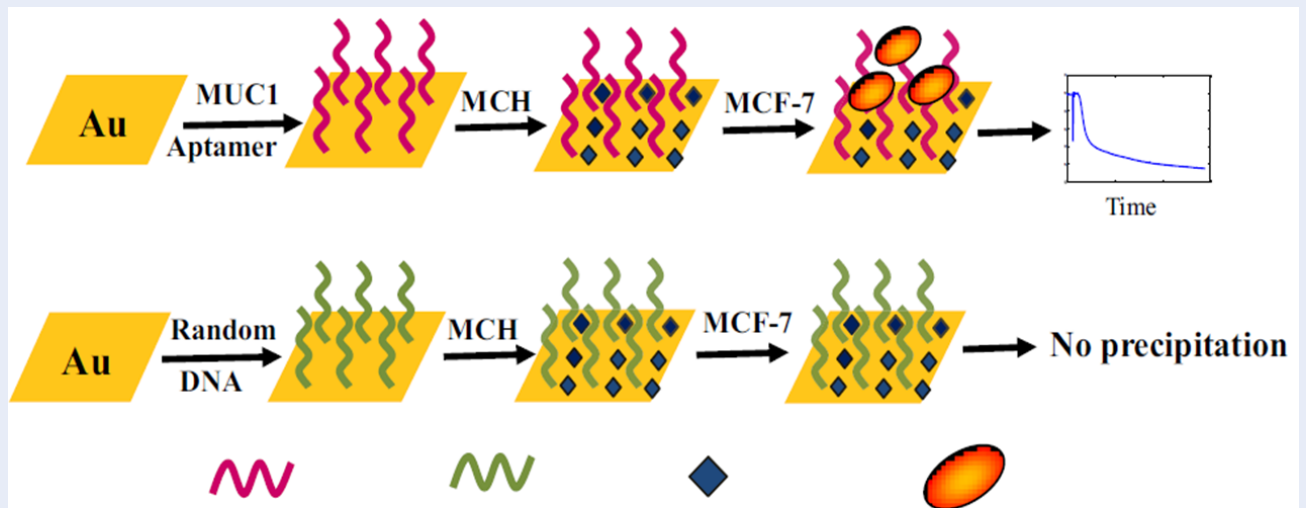

MUC1 Aptamer Random DNA MCH MCF-7

Figure 1: Schematic presentation of an aptasensor against MCF-7 cells ${ }^{58}$ (permission number: 4006910414095).

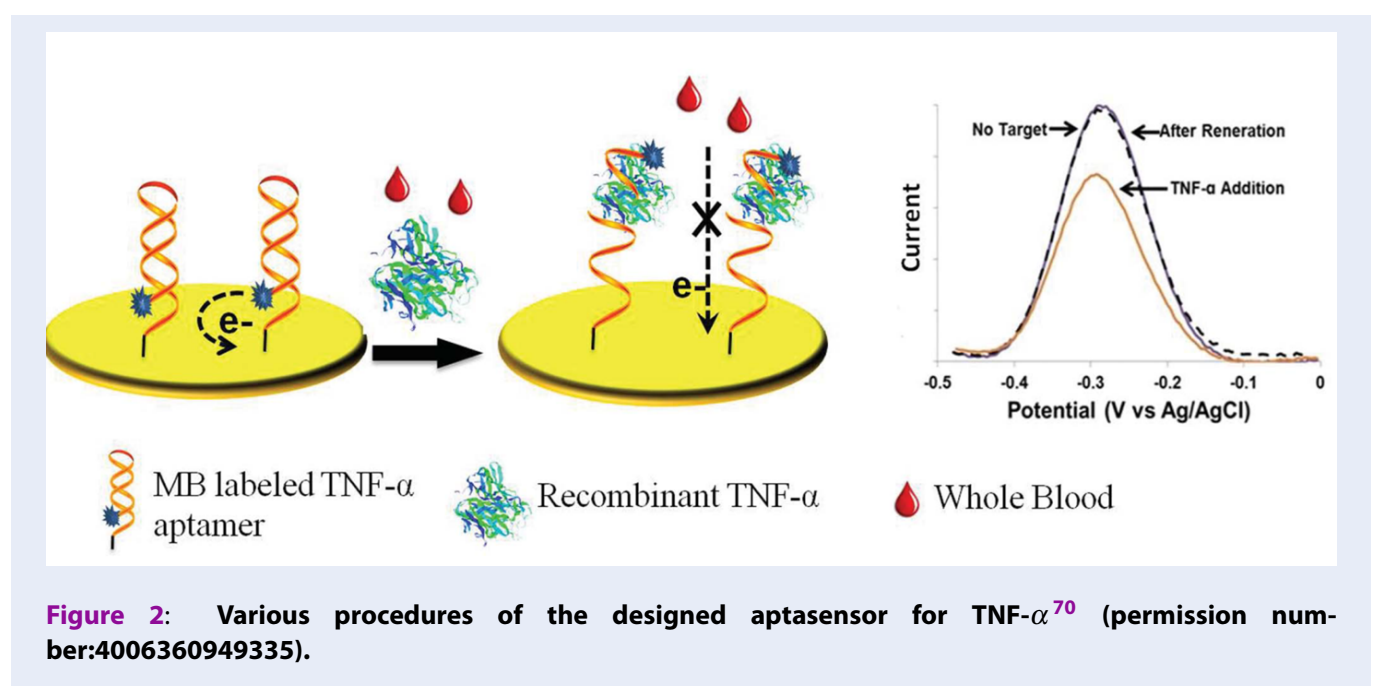

the range of $0.001 \mathrm{ng} \mathrm{mL}^{-1}$ to $100 \mathrm{ng} \mathrm{mL}^{-171}$. Here, the cucurbituril 7 (CB)/nano gold@chitosan was used as the signal facilitator and this led to finding the LOD about $0.5 \mathrm{pg} \mathrm{mL}^{-1}$. In addition, as mentioned in section 3, TNF- $\alpha$ detection was also applied for prostate cancer diagnosis ${ }^{70}$.

\section{APTASENSORS FOR DETECTION THE LEUKEMIA CELLS}

In a research, Cao et al. tried to investigate a signalon aptasensor in order to detect the T-cell acute lymphoblastic leukemia cells (CCRF-CEM cells) ${ }^{72}$; they used of GO-based fluorescence resonance energy transfer (FRET) in the sensing strategy and the detection results showed a linear range $\left(2.5 \times 10^{1}\right.$ to $2.5 \times$ $10^{4}$ cells $\mathrm{mL}^{-1}$ ) against CCRF-CEM cells. In another research, in order to detect of the adenosine in the cancer cells, an electrochemiluminescence aptasensor using a wireless indium tin oxide bipolar electrode (BPE) was reported ${ }^{73}$. This aptasensor could detect the adenosine triphosphate (ATP) in a linear range from $1.0 \mathrm{fM}$ to $0.10 \mu \mathrm{M}$. The results of this research were used in the diagnosis of K562 leukemia cells. Graphene was used in an electrochemical aptasensor for detection of the HeLa cells (human cervical carcinoma cell), MDA-MB-231 (human breast cancer cell), K562 cells (leukemia line), and NIH3T3 cells (mouse embryonic fibroblast cell line) ${ }^{74}$. The growth and proliferation of HeLa cells and their viability at various times on 3,4,9,10-perylene tetracarboxylic acid PTCA-functionalized chemical converted graphene (PTCA/CCG) are shown in Figure 3. 

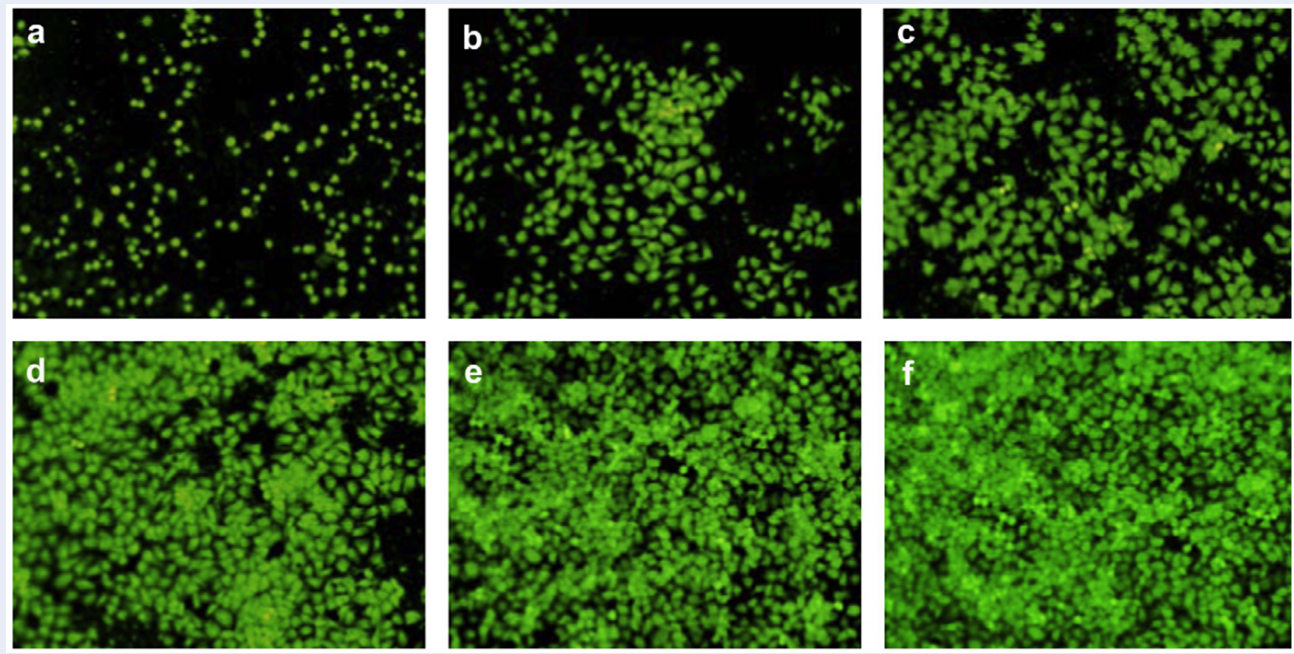

Figure 3: Fluorescence evaluation of HeLa cells that were cultivated on PTCA/CCG and aptamer-modified glass slides at various times (a) 2 hours, (b) 8 hours, (c) 12 hours, (d) 24 hours, (e) 48 hours, (f) 72 hours. Then stain the live cells with acridine orange (AO) dye molecules ${ }^{74}$ (permission number: 4017490002653).

The results of this research showed the more successful detection method for HeLa cells (human cervical carcinoma cell) and MDA-MB-231 (human breast cancer cell). In this research, electrochemical measurements were performed through CV and EIS and the redox marker was $\mathrm{K}_{3}\left[\mathrm{Fe}(\mathrm{CN})_{6}\right]$. An electrochemical aptasensor was designed to detect HeLa cells at the range of 10 to $10^{6}$ cells $\mathrm{mL}^{-175}$. This aptasensor was based on the graphene nanocomposites that this material led to amplification of the detectable signal produced by the analyte. A visual colorimetric aptasensor was designed based on cell-triggered cyclic enzymatic signal amplification ${ }^{76}$. This aptasensor could detect T-cell acute lymphoblastic leukemia cells (CCRFCEM cells) in the range of $10^{2}$ to $10^{4}$ cells and the AuNPs with a diameter of $13 \mathrm{~nm}$ were used as the aptamer modifier. Using an electrochemiluminescence adenosine aptasensor was followed by Tian et al. ${ }^{77}$. Photocatalytic properties of $\mathrm{TiO}_{2}$ nanotubes were used in the mentioned aptasensor and it showed a $3.32 \pm 0.2 \mathrm{pmol} /$ cell detection value against $\mathrm{K} 562$ cells.

\section{APTASENSORS FOR DETECTION OF MUC1 CELLS AND MUC1 APPLICATION IN THEM}

Over-expressing the MUC1 glycoprotein is the very important sign and marker to detecting cancer; A fluorescent aptasensor was designed to detect the $\mathrm{MUC1}^{78}$; the GO was used as the signal quencher.
In this research, the analyses were performed through a fluorescence spectrophotometer. He et al. could detect MUC1 in the range of 0.04 to $10 \mu \mathrm{M}$. In another research, Liu et al. designed an aptasensor in order to detect of the MUC1 tumor marker ${ }^{79}$; in this research, electrochemical measurements were performed through EIS technique and the redox marker was $\left[\mathrm{Fe}(\mathrm{CN})^{3-/ 4-}\right]$. Liu et al. applied two work methods due to detecting the MUC1 (Figure 4); they used of bare gold electrode and modified gold electrode with Au nanoparticles; when they used of the modified gold electrode with $\mathrm{Au}$ nanoparticles, the aptasensor showed a significant amplification response against MUC1 and this situation was related to three-dimensional structure and conformation changes in the used thiolated DNA aptamer when Au nanoparticles existed.

According to the author's claims, this aptasensor was able to detect MUC1 at very low concentration (0.1 $\mathrm{nM}$ ) and showed the high selectivity, reproducibility, and stability. Other related researches in order to detect of the MUC1 also was mentioned before in section $2^{48}$. In an aptasensor, EIS and CV techniques were used to detect the colon cancer DLD- 1 cells ${ }^{80}$. The authors of this research used of MUC1 aptamer and carbon nanospheres (CNSs) with an average diameter of $500 \mathrm{~nm}$; using of the conjugated MUC1 aptamer with CNSs had led to the detection of the colon cancer DLD- 1 cells in the range of $1.25 \times 10^{2}$ to $1.25 \times 10^{6}$ cells $\mathrm{mL}^{-1}$. Cao et al. tried to offer 


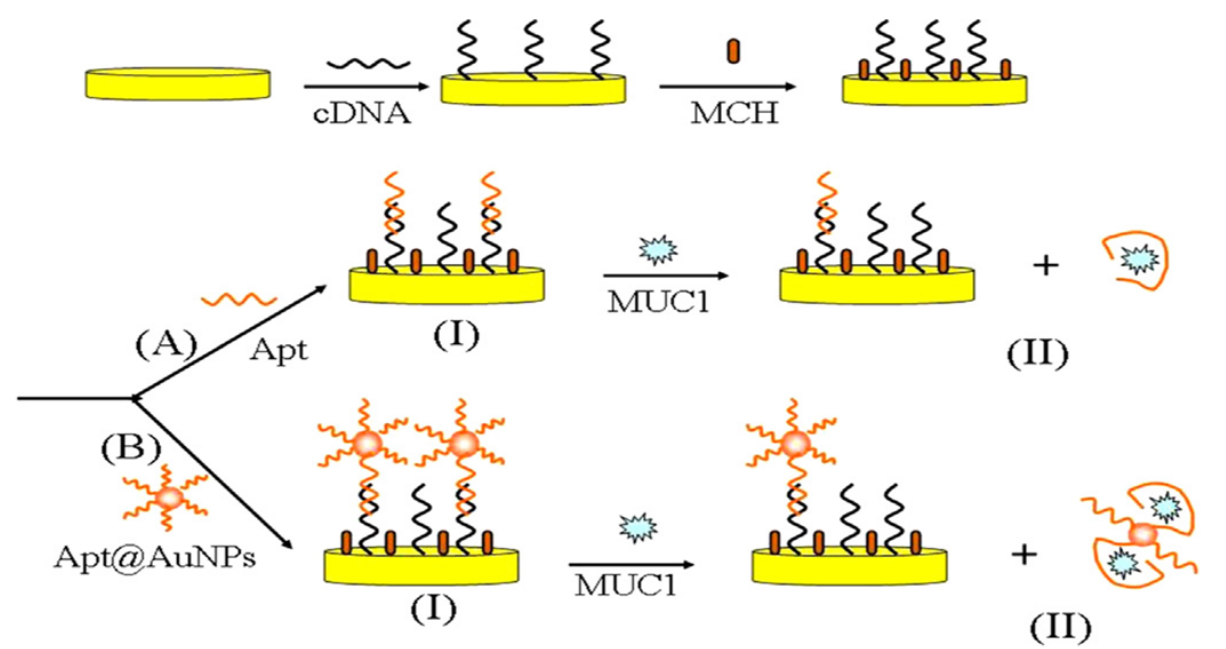

Figure 4: Schematic illustration of the designed aptasensor for MUC1 ${ }^{79}$ (permission number: 4006590269262).

an early diagnosis method for diagnosis of the colon cancer through detection the MUC1 glycoprotein on the cellular membrane. As previously cited, Chang et al. used a specific MUC1 aptamer in order to diagnosis the MCF-7 cells ${ }^{58}$. Other try for detection the MUC1was related to $\mathrm{Li}$ et al. research that was presented in section $4^{65}$.

\section{APTASENSORS FOR DETECTION THE CARCINOEMBRYONIC ANTIGEN (CEA)}

An electrochemiluminescence aptasensor was designed to detect the CEA in the real human serums samples ${ }^{81}$; in this aptasensor, cadmium sulfide graphene nanocomposites were used as coreactant. This aptasensor could detect CEA at the range of 0.01 to $10.0 \mathrm{ng} \mathrm{mL}^{-1}$. In other work, electrochemiluminescence CEA assay was investigated through a nanoaptasensor containing nanocomposites (ZnS-CdS nanoparticles (NPs)-decorated molybdenum disulfide $\left(\mathrm{MoS}_{2}\right)$. The mentioned nanomaterials were used to provide a high loading analyte capacity $^{82}$; this aptasensor showed a linear detection range $\left(0.05\right.$ to $\left.20 \mathrm{ng} \mathrm{mL}^{-1}\right)$ versus CEA. A FRET based aptasensor was designed to detect $\mathrm{CEA}^{83}$. In this aptasensor, carbon nanoparticles (CNPs) and an amino group-modified aptamer were used, and the found results showed a linear detection range $(0.1$ to $40 \mathrm{ng} \mathrm{mL}{ }^{-1}$ ) against CEA. An electrochemical aptasensor was designed to detect the CEA. In the structure of this aptasensor, a nanocomposite of gold nanoparticles, hemin, and graphene were applied ${ }^{84}$. This aptasensor could detect CEA in the range of 0.0001 to $10 \mathrm{ng} \mathrm{mL}^{-1}$ and LOD for it was $40 \mathrm{~mL}^{-1}$. In Table 1, most usual methods used for detection of CEA are cited.

\section{OTHER APPLICATIONS OF APTASENSORS IN THE CANCER FOLLOW-UP}

In a research, an aptasensor was designed to detect the cytochrome $c^{91}$. This aptasensor was used to investigate the drug treatment in the liver cancer; the screen mechanism was related to diagnosis of $\mathrm{cy}$ tochrome $c$; cytochrome $c$ role in apoptosis as one of the fighter processes against cancer is clear, so that the B-cell lymphoma 2 ( $\mathrm{Bcl}-2)$ regulatory protein is the cause in order to release the cytochrome $c$ from the mitochondria, which leads to the activation of caspase- 9 and then caspase-3; eventually, this pathway leads to cell apoptosis ${ }^{92}$. A way analytics method to detect the cytochrome $c$ was SPR that performed through common-path spectral interferometry. Loo et al found an aptasensor that could detect cytochrome $c$ in the range of $80 \mathrm{nM}$ to $80 \mathrm{pM}$. In another electroanalytical work, Kara et al designed an aptasensor for detecting the adenocarcinoma type lung cancer. In this research, the cytosensing platform and EIS technique with $\left[\mathrm{Fe}(\mathrm{CN})_{6}{ }^{3-/ 4-}\right]$ as redox marker were used $^{93}$. The obtained LOD for this aptasensor was 163.7 cells $\mathrm{mL}^{-1}$; the selectivity of this aptasensor was compared with other cancers (human hepatic 


\begin{tabular}{|c|c|c|}
\hline Detection technique & Detection range & Reference \\
\hline Electrochemiluminescence aptasensing & $0.01-10.0 \mathrm{ng} \mathrm{mL}^{-1}$ & 81 \\
\hline Electrochemiluminescence aptasensing & 0.05 to $20 \mathrm{ng} \mathrm{mL}^{-1}$ & 82 \\
\hline FRET based aptasensor & 0.1 to $40 \mathrm{ng} \mathrm{mL}^{-1}$ & 83 \\
\hline Electrochemical aptasensing & 0.0001 to $10 \mathrm{ng} \mathrm{mL}^{-1}$ & 84 \\
\hline Qualitative Analysis & cutoff value was $2.5 \mathrm{ng} / \mathrm{L}$ & 85 \\
\hline Qualitative Analysis & cutoff value was $7 \mathrm{mg} / \mathrm{L}$ & 86 \\
\hline Qualitative Analysis & up to $32 \mu \mathrm{g} / \mathrm{L}$ & 87 \\
\hline Luminescence Assay & --- & 88 \\
\hline latex photometric immunoassay (LPIA) & --- & 89 \\
\hline Qualitative Analysis & $10 \mathrm{ng} \mathrm{ml}^{-1}$ & 90 \\
\hline
\end{tabular}

cancer HepG2 \& human cervical cancer HeLA cells); the final results of the mentioned work showed that this aptasensor was highly selective versus A549 cell line. Designing a specific aptasensor in order to detect the human hepatoma SMMC-7721 cells was followed by Yuan et al. ${ }^{94}$. This aptasensor was based on FRET and the found results were approved with flow cytometry assay. In this study, the Cy3 and Cy5 fluorescent group were labeled and applied on the used aptamer; during detection of the analyte, the FRET signal appeared for low amounts of SMMC-7721 cells (LOD: 20 cells in $200 \mu \mathrm{L}$ ). An electrochemical aptasensor was designed to detect the LC-18 tumor marker in lung cancer patients ${ }^{94}$. The LOD against LC-18 was about $0.023 \mathrm{ng} \mathrm{mL}^{-1}$. In electrochemical studies, SWV was used as the main analyte analysis technique. In a research, Hashemian et al designed a fluorescence aptasensor based on FRET (between CdS quantum dot (QDs)) in order to the detection of adenosine in urine samples of the lung cancer patients ${ }^{90}$. This aptasensor could determine the adenosine in a linear range of 23 to $146 \mathrm{nM}$ while LOD was $9.3 \mathrm{nM}$. Qureshi et al. tried to offer a new way for detection of the human epidermal growth factor receptor 2 (HER2) cancer biomarker $\left(0.2 \text { to } 2 \mathrm{ng} \mathrm{mL}{ }^{-1}\right)^{92}$; in this aptasensor, the detection method was based on changing the dielectric parameters (impedance/capacitance). Visual monitoring of cancer biomarker anterior gradient homolog 2 (AGR2) was followed through an aptasensor using UV-vis spectrometry ${ }^{93}$. This aptasensor could detect AGR2 at the linear range of 10 to 1280 pM with LOD 6.6 pM. An aptasensor was introduced for liver cancer through the detection of HepG2 cells in the range of $1 \times 10^{3}$ to $1 \times 10^{5}$ cells $\mathrm{mL}^{-194}$. Analytical section of this aptasensor was based on commercial cantisens sensor platform and microcantilevers.

\section{CONCLUSION}

We know, regardless of nationality, cancers are one of the main mortality causes in the world. The exact cause of cancer is unknown and likelyprobable genetic factors or other issues that interfere with the activity of cells are involved in the incidence of these diseases. The aims of medicine are health promotion, maintain, restore health, reduce pain and reduce disability. One of the most important steps to achieve this goal is to prevent the spread of cancers when they are in the early stages. Moreover, trying to make ways for early diagnosis and also choosing the appropriate treatment are very necessary against cancers. The extensive researches are performed in order to find early detection, low cost, easy and accurate methods against cancers. The routine cancer diagnostic applied methods are often invasive and expensive; in addition, in very small quantities, these methods cannot detect early tumors. Aptamers as molecular structures have been used in the structure of aptasensors in order to diagnosis the many cancers with high affinity. Using advanced nanostructures and the functionalized aptamer with some organic materials has increased the diagnostic sensitivity and specificity of aptasensors. As the specificity and sensitivity of the aptasensors is been higher, makes them appropriate commercial diagnostic tools for the early diagnosis of cancers. It is hoped that the researches will reduce the effects of interfering factors in cancer aptasensors; also, by integrating other technologies, the more accurate and portable diagnostic cancer tools such as commercial aptasensors will be produced.

\section{CONFLICT OF INTEREST}

The authors declare that there is no conflict of interest regarding the publication of this paper. 


\section{AUTHORS' CONTRIBUTIONS}

All authors contributed substantially to the conception and design of the study.

\section{ACKNOWLEDGMENTS}

We would like to thank the Research Council of Shiraz University of Medical Sciences (20336) for supporting this research.

\section{REFERENCES}

1. Kunst A, Stronks K, Agyemang C. Non-communicable diseases. Migration and health in the European Union. 2011;1(116).

2. McQueen DV. Global Handbook on Noncommunicable Diseases and Health Promotion. New York: Springer; 2016.

3. Shankar S, Srivastava RK. Nutrition, Diet and Cancer. Netherlands: Springer; 2015.

4. Stanner S, Foundation BN. Cardiovascular Disease: Diet, Nutrition and Emerging Risk Factors (The Report of the British Nutrition Foundation Task Force). Wiley; 2008.

5. Wu S, Powers S, Zhu W, Hannun YA. Substantial contribution of extrinsic risk factors to cancer development. Nature. 2016;529(7584):43-7. PMID: 26675728. Available from: 10. 1038/nature16166.

6. Fedewa SA, Sauer AG, Siegel RL, Jemal A. Prevalence of major risk factors and use of screening tests for cancer in the United States. Cancer Epidemiol Biomarkers Prev. 2015;24(4):637-52. PMID: 25834147. Available from: 10.1158/1055-9965.EPI-150134 .

7. Boughton B, Gansler T, Stefanek M. Reduce Your Cancer Risk: Twelve Steps To A Healthier Life. Springer Publishing Company; 2010.

8. Medicine I, Health BG, Gelband H, Sloan FA, Countries CC. Cancer Control Opportunities in Low- and Middle-Income Countries. National Academies Press; 2007.

9. Wardle J, Robb K, Vernon S, Waller J. Screening for prevention and early diagnosis of cancer. Am Psychol. 2015;70(2):119-33. PMID: 25730719. Available from: 10.1037/a0037357.

10. Jin Z, Jiang W, Wang L. Biomarkers for gastric cancer: progression in early diagnosis and prognosis (Review). Oncol Lett. 2015;9(4):1502-8. PMID: 25788990. Available from: 10.3892/ol.2015.2959.

11. Barh D, Carpi A, Verma M, Gunduz M. Cancer Biomarkers: Minimal and Noninvasive Early Diagnosis and Prognosis. Taylor \& Francis; 2014. Available from: 10.1201/b16389.

12. Gearhart S, Ahuja N, Yang SC. Early Diagnosis and Treatment of Cancer Series: Colorectal Cancer: Expert Consult. Elsevier Health Sciences; 2010.

13. Mascarenhas $L$, Felgenhauer JL, Bond MC, Villaluna D, Femino JD, Laack NN, et al. Pilot Study of Adding Vincristine, Topotecan, and Cyclophosphamide to Interval-Compressed Chemotherapy in Newly Diagnosed Patients With Localized Ewing Sarcoma: A Report From the Children's Oncology Group. Pediatr Blood Cancer. 2016;63(3):493-8. PMID: 26579879. Available from: 10.1002/pbc. 25837.

14. Hayat MA. Methods of Cancer Diagnosis, Therapy, and Prognosis: Brain Cancer. Springer Netherlands; 2010.

15. Brown BJ, Adeleye AO, Ibeh JN. A prospective study on the causes of delayed diagnosis of childhood cancer in Ibadan, Nigeria. Pediatr Hematol Oncol. 2015;32(6):365-73. PMID: 26086955. Available from: 10.3109/08880018.2015.1040933.

16. Car LT, Papachristou N, Bull A, Majeed A, Gallagher J, El-Khatib $M$, et al. Clinician-identified problems and solutions for delayed diagnosis in primary care: a PRIORITIZE study. BMC Fam Pract. 2016;17(1):131. PMID: 27613564. Available from: 10.1186/s12875-016-0530-z.

17. Seneviratne S, Campbell I, Scott N, Coles C, Lawrenson R. Treatment delay for Māori women with breast cancer in New
Zealand. Ethn Health. 2015;20(2):178-93. PMID: 24635721. Available from: 10.1080/13557858.2014.895976.

18. Lo PC, Dahlberg SE, Nishino M, Johnson BE, Sequist LV, Jackman DM, et al. Delay of treatment change after objective progression on first-line erlotinib in epidermal growth factor receptor-mutant lung cancer. Cancer. 2015;121(15):2570-7. PMID: 25876525. Available from: 10.1002/cncr.29397.

19. DeSantis CE, Siegel RL, Sauer AG, Miller KD, Fedewa SA, Alcaraz $\mathrm{Kl}$, et al. Cancer statistics for African Americans, 2016: progress and opportunities in reducing racial disparities. CA Cancer J Clin. 2016;66(4):290-308. PMID: 26910411. Available from: $10.3322 /$ caac. 21340 .

20. Siegel RL, Miller KD, Jemal A. Cancer statistics, 2016. CA Cancer J Clin. 2016;66(1):7-30. PMID: 26742998. Available from: 10. 3322/caac. 21332.

21. Sattarahmady N, Heli $H$, Mehdizadeh AR, Yarmohammadi $H$, Mortazavi SM. Evaluation of Serum Catalase Activity and Malondialdehyde Level as Stress Oxidative Biomarkers among Iranian Welders. Galen Med J. 2015;4(3):62-6.

22. Peters KE, Peters KE, Walters CC, Moldowan J. The biomarker guide. Cambridge University Press; 2005.

23. Sawyers $\mathrm{CL}$. The cancer biomarker problem. Nature. 2008;452(7187):548-52. PMID: 18385728. Available from: $10.1038 /$ nature 06913 .

24. Verma M. Epigenetic biomarkers in cancer epidemiology. Cancer Epigenetics. Springer; 2012.

25. Ravelli A, Reuben JM, Lanza F, Anfossi S, Cappelletti MR, Zanotti L, et al. Breast cancer circulating biomarkers: advantages, drawbacks, and new insights. Tumour Biol. 2015;36(9):665365. PMID: 26307395. Available from: 10.1007/s13277-0153944-7.

26. Hermann T, Patel DJ. Adaptive recognition by nucleic acid aptamers. Science. 2000;287(5454):820-5. PMID: 10657289. Available from: 10.1126/science.287.5454.820.

27. Brody EN, Gold L. Aptamers as therapeutic and diagnostic agents. J Biotechnol. 2000;74(1):5-13. PMID: 10943568. Available from: 10.1016/S1389-0352(99)00004-5.

28. Tombelli S, Minunni M, Mascini M. Analytical applications of aptamers. Biosens Bioelectron. 2005;20(12):2424-34. PMID: 15854817. Available from: 10.1016/j.bios.2004.11.006.

29. Nilsen-Hamilton M. Aptamers in Bioanalysis. J Am Chem Soc. 2009:131(33):12018. Available from: 10.1021/ja906077x.

30. Iliuk $A B, H u L$, Tao WA. Aptamer in bioanalytical applications. Anal Chem. 2011;83(12):4440-52. PMID: 21524128. Available from: $10.1021 /$ ac201057w.

31. Mascini M. Aptamers in Bioanalysis. Wiley; 2009. Available from: 10.1002/9780470380772.

32. Lyons G. Development of an Electrochemical Aptasensor for Ghrelin Detection: NUI, 2006 at Department of Analytical Chemistry. UCC; 2006.

33. O'Sullivan CK. Aptasensorsfuture of biosensing? Anal Bioana Chem. 2002;372(1):44-8. PMID: 11939212. Available from: 10 1007/s00216-001-1189-3.

34. Luzi E, Minunni M, Tombelli $S$, Mascini M. New trends in affinity sensing: aptamers for ligand binding. Trends Analyt Chem. 2003;22(11):810-8. Available from: 10.1016/S0165-9936(03) 01208-1.

35. Hianik T, Wang J. Electrochemical aptasensorsachievements and perspectives. Electroanalysis. 2009;21(11):1223-35. Available from: 10.1002/elan.200904566.

36. Chen X, Zhang Q, Qian C, Hao N, Xu L, Yao C. Electrochemical aptasensor for mucin 1 based on dual signal amplification of poly(o-phenylenediamine) carrier and functionalized carbon nanotubes tracing tag. Biosens Bioelectron. 2015;64:485-92. PMID: 25290645. Available from: 10.1016/j.bios.2014.09.052.

37. Robati RY, Arab A, Ramezani M, Langroodi FA, Abnous K, Taghdisi SM. Aptasensors for quantitative detection of kanamycin Biosens Bioelectron. 2016;82:162-72. PMID: 27085947. Available from: 10.1016/j.bios.2016.04.011.

38. Cheng L, Zhang J, Lin Y, Wang Q, Zhang $X$, Ding $Y$, et al. An electrochemical molecular recognition-based aptasensor for 
multiple protein detection. Anal Biochem. 2015;491:31-6. PMID: 26344894. Available from: 10.1016/j.ab.2015.08.023.

39. Sattarahmady N, Rahi A, Heli H. A signal-on built in-marker electrochemical aptasensor for human prostate-specific antigen based on a hairbrush-like gold nanostructure. Sci Rep. 2017;7(1):11238. PMID: 28894225. Available from: 10.1038/ s41598-017-11680-5.

40. Negahdary M, Behjati-Ardakani M, Sattarahmady N, Yadegari $\mathrm{H}$, Heli $\mathrm{H}$. Electrochemical aptasensing of human cardiac troponin I based on an array of gold nanodumbbells-Applied to early detection of myocardial infarction. Sens Actuators B Chem. 2017;252:62-71. Available from: 10.1016/j.snb.2017.05. 149.

41. Negahdary M, Behjati-Ardakani M, Sattarahmady N, Heli H. An Aptamer-based Biosensor for Troponin I Detection in Diagnosis of Myocardial Infarction. J Biomed Phys Eng. 2018;8(2):167-78. PMID: 29951443. Available from: 10.31661/ jbpe.v8i2.930.

42. Negahdary M, Behjati-Ardakani M, Heli H. An electrochemical troponin T aptasensor based on the use of a macroporous gold nanostructure. Mikrochim Acta. 2019;186(6):377. PMID: 31134399. Available from: 10.1007/s00604-019-3472-z.

43. Negahdary M, Heli $\mathrm{H}$. An ultrasensitive electrochemical aptasensor for early diagnosis of Alzheimer's disease, using a fern leaves-like gold nanostructure. Talanta. 2019;198:5107. PMID: 30876593 . Available from: 10.1016/j.talanta.2019.01. 109.

44. Qureshi A, Roci I, Gurbuz Y, Niazi JH. VEGF Cancer Biomarker Protein Detection in Real Human Serum Using Capacitive Label-Free Aptasensor. Macromolecular Symposia. Wiley Online Library; 2015.

45. Zhao J, He X, Bo B, Liu X, Yin Y, Li G. A electrochemical aptasensor for simultaneous detection of two tumor markers. Biosens Bioelectron. 2012;34(1):249-52. PMID: 22386488. Available from: 10.1016/j.bios.2012.02.016.

46. Cho $H$, Yeh EC, Sinha R, Laurence TA, Bearinger JP, Lee LP. Single-step nanoplasmonic VEGF165 aptasensor for early cancer diagnosis. ACS Nano. 2012;6(9):7607-14. PMID: 22880609. Available from: $10.1021 / \mathrm{nn} 203833 \mathrm{~d}$.

47. Tabrizi MA, Shamsipur M, Farzin L. A high sensitive electrochemical aptasensor for the determination of VEGF(165) in serum of lung cancer patient. Biosens Bioelectron. 2015;74:764-9. PMID: 26217879. Available from: 10.1016/j. bios.2015.07.032.

48. Cennamo N, Pesavento M, Lunelli L, Vanzetti L, Pederzolli C, Zeni L, et al. An easy way to realize SPR aptasensor: A multimode plastic optical fiber platform for cancer biomarkers detection. Talanta. 2015;140:88-95. PMID: 26048828. Available from: 10.1016/j.talanta.2015.03.025.

49. Jolly P, Formisano N, TkáJ, Kasák P, Frost CG, Estrela P. Labelfree impedimetric aptasensor with antifouling surface chemistry: a prostate specific antigen case study. Sens Actuators B Chem. 2015;209:306-12. Available from: 10.1016/j.snb.2014. 11.083 .

50. Liu B, Lu L, Hua E, Jiang S, Xie G. Detection of the human prostate-specific antigen using an aptasensor with gold nanoparticles encapsulated by graphitized mesoporous carbon. Mikrochim Acta. 2012;178(1-2):163-70. Available from: 10.1007/s00604-012-0822-5.

51. Rahi A, Sattarahmady N, Heli H. Label-free electrochemical aptasensing of the human prostate-specific antigen using gold nanospears. Talanta. 2016;156-157:218-24. PMID: 27260456. Available from: 10.1016/j.talanta.2016.05.029.

52. Tahmasebi F, Noorbakhsh A. Sensitive Electrochemical Prostate Specific Antigen Aptasensor: Effect of Carboxylic Acid Functionalized Carbon Nanotube and Glutaraldehyde Linker. Electroanalysis. 2016;28(5):1134-45. Available from: 10.1002/elan.201501014.

53. Cha T, Cho S, Kim YT, Lee JH. Rapid aptasensor capable of simply diagnosing prostate cancer. Biosens Bioelectron. 2014;62:31-7. PMID: 24973540. Available from: 10.1016/j.bios. 2014.06.015.
54. Cai S, Chen M, Liu M, He W, Liu Z, Wu D, et al. A signal amplification electrochemical aptasensor for the detection of breast cancer cell via free-running DNA walker. Biosens Bioelectron. 2016;85:184-9. PMID: 27176917. Available from: 10.1016/j.bios.2016.05.003.

55. Chang K, Pi Y, Lu W, Wang F, Pan F, Li F. Label-free and highsensitive detection of human breast cancer cells by aptamerbased leaky surface acoustic wave biosensor array. Biosensors and Bioelectronics. 2014;(60):318-24. Available from: 10.1016/j.bios.2014.04.027.

56. Ilgu $M$, Nilsen-Hamilton $M$. Aptamers in analytics. Analyst (Lond). 2016;141(5):1551-68. PMID: 26864075. Available from: 10.1039/C5AN01824B.

57. Cai S, Li G, Zhang X, Xia Y, Chen M, Wu D, et al. A signal-on fluorescent aptasensor based on single-stranded DNA-sensitized luminescence of terbium (III) for label-free detection of breast cancer cells. Talanta. 2015;138:225-30. PMID: 25863395. Available from: 10.1016/j.talanta.2015.02.056.

58. Liang L, Su M, Li L, Lan F, Yang G, Ge S, et al. Aptamer-based fluorescent and visual biosensor for multiplexed monitoring of cancer cells in microfluidic paper-based analytical devices. Sens Actuators B Chem. 2016;229:347-54. Available from: 10. 1016/j.snb.2016.01.137.

59. Li Y, Zhang $Y$, Zhao $M$, Zhou Q, Wang L, Wang H, et al. A simple aptamer-functionalized gold nanorods based biosensor for the sensitive detection of MCF-7 breast cancer cells. Chem Commun (Camb). 2016;52(20):3959-61. PMID: 26882343. Available from: 10.1039/C6CC01014H.

60. Borghei YS, Hosseini M, Dadmehr M, Hosseinkhani S, Ganjali MR, Sheikhnejad R. Visual detection of cancer cells by colorimetric aptasensor based on aggregation of gold nanoparticles induced by DNA hybridization. Anal Chim Acta. 2016;904:92-7. PMID: 26724767. Available from: 10.1016/j. aca.2015.11.026.

61. Yan M, Sun G, Liu F, Lu J, Yu J, Song X. An aptasensor for sensitive detection of human breast cancer cells by using porous $\mathrm{GO} / \mathrm{Au}$ composites and porous PtFe alloy as effective sensing platform and signal amplification labels. Anal Chim Acta. 2013;798:33-9. PMID: 24070481. Available from: 10.1016/j. aca.2013.08.046.

62. Li C, Meng Y, Wang S, Qian M, Wang J, Lu W, et al. Mesoporous Carbon Nanospheres Featured Fluorescent Aptasensor for Multiple Diagnosis of Cancer in Vitro and in Vivo. ACS Nano. 2015;9(12):12096-103. PMID: 26575351. Available from: 10.1021/acsnano.5b05137.

63. Wang K, Zhang R, Sun N, Li X, Wang J, Cao Y, et al. Near-Infrared Light-Driven Photoelectrochemical Aptasensor Based on the Upconversion Nanoparticles and TiO2/CdTe Heterostructure for Detection of Cancer Cells. ACS Appl Mater Interfaces. 2016;8(39):25834-9. PMID: 27627052. Available from: 10 1021/acsami.6b09614.

64. Yu F, Li G, Mao C. An electrochemiluminescence aptasensor for tumor cells assay based on signal amplification of Ru (II) covalently doped silica nanoparticles. Electrochem Commun. 2011;13(11):1244-7. Available from: 10.1016/j.elecom.2011. 08.033 .

65. Liu G, Mao X, Phillips JA, Xu H, Tan W, Zeng L. Aptamernanoparticle strip biosensor for sensitive detection of cancer cells. Anal Chem. 2009;81(24):10013-8. PMID: 19904989. Available from: 10.1021/ac901889s.

66. van Horssen R, Hagen TLT, Eggermont AM. TNF- $\alpha$ in cancer treatment: molecular insights, antitumor effects, and clinical utility. Oncologist. 2006;11(4):397-408. PMID: 16614236. Available from: 10.1634/theoncologist.11-4-397.

67. Liu Y, Zhou Q, Revzin A. An aptasensor for electrochemical detection of tumor necrosis factor in human blood. Analyst (Lond). 2013;138(15):4321-6. PMID: 23745180. Available from: 10.1039/c3an00818e.

68. Liu L, Liu F, Jiang D, Xiang G, Liu C, Yang J, et al. Hybridization chain reaction and target recycling enhanced tumor necrosis factor alpha aptasensor with host-guest interaction for sig- 
nal probe collection. Sens Actuators B Chem. 2016;231:680-7. Available from: 10.1016/j.snb.2016.03.098.

69. Cao L, Cheng L, Zhang Z, Wang Y, Zhang $X$, Chen $H$, et al. Visual and high-throughput detection of cancer cells using a graphene oxide-based FRET aptasensing microfluidic chip. Lab Chip. 2012;12(22):4864-9. PMID: 23023186. Available from: 10.1039/c2lc40564d.

70. Shi HW, Wu MS, Du Y, Xu JJ, Chen HY. Electrochemiluminescence aptasensor based on bipolar electrode for detection of adenosine in cancer cells. Biosens Bioelectron. 2014;55:45963. PMID: 24441543. Available from: 10.1016/j.bios.2013.12. 045.

71. Feng L, Chen Y, Ren J, Qu X. A graphene functionalized electrochemical aptasensor for selective label-free detection of cancer cells. Biomaterials. 2011;32(11):2930-7. PMID: 21256585. Available from: 10.1016/j.biomaterials.2011.01.002.

72. Wang T, Liu J, Gu X, Li D, Wang J, Wang E. Label-free electrochemical aptasensor constructed by layer-by-layer technology for sensitive and selective detection of cancer cells. Anal Chim Acta. 2015;882:32-7. PMID: 26043089. Available from: 10.1016/j.aca.2015.05.008.

73. Zhang X, Xiao K, Cheng L, Chen H, Liu B, Zhang S, et al. Visual and highly sensitive detection of cancer cells by a colorimetric aptasensor based on cell-triggered cyclic enzymatic signal amplification. Anal Chem. 2014;86(11):5567-72. PMID: 24819867. Available from: 10.1021/ac501068k.

74. Tian CY, Xu JJ, Chen HY. A novel aptasensor for the detection of adenosine in cancer cells by electrochemiluminescence of nitrogen doped $\mathrm{TiO} 2$ nanotubes. Chem Commun (Camb). 2012;48(66):8234-6. PMID: 22781811. Available from: $10.1039 / \mathrm{c} 2 \mathrm{cc} 34229 \mathrm{~d}$.

75. He Y, Lin Y, Tang H, Pang D. A graphene oxide-based fluorescent aptasensor for the turn-on detection of epithelial tumor marker mucin 1. Nanoscale. 2012;4(6):2054-9. PMID: 22336777. Available from: 10.1039/c2nr12061e.

76. Liu X, Qin Y, Deng C, Xiang J, Li Y. A simple and sensitive impedimetric aptasensor for the detection of tumor markers based on gold nanoparticles signal amplification. Talanta. 2015;132:150-4. PMID: 25476292. Available from: 10.1016/ j.talanta.2014.08.072.

77. Cao H, Ye D, Zhao Q, Luo J, Zhang S, Kong J. A novel aptasensor based on MUC-1 conjugated CNSs for ultrasensitive detection of tumor cells. Analyst (Lond). 2014;139(19):4917-23. PMID: 25078888. Available from: 10.1039/C4AN00844H.

78. Shi GF, Cao JT, Zhang JJ, Huang KJ, Liu YM, Chen YH, et al. Aptasensor based on tripetalous cadmium sulfide-graphene electrochemiluminescence for the detection of carcinoembryonic antigen. Analyst (Lond). 2014;139(22):5827-34. PMID: 25209409. Available from: 10.1039/C4AN01311E.

79. Wang YL, Cao JT, Chen YH, Liu YM. A label-free electrochemiluminescence aptasensor for carcinoembryonic antigen detection based on electrodeposited ZnSCdS on MoS 2 decorated electrode. Anal Methods. 2016;8(26):5242-7. Available from: 10.1039/C6AY01114D.

80. Wu Z, Li H, Liu Z. An aptasensor for carcinoembryonic antigen based on upconversion fluorescence resonance energy transfer. Sens Actuators B Chem. 2015;206:531-7. Available from: 10.1016/j.snb.2014.09.084.

81. Liu Z, Wang Y, Guo Y, Dong C. Label-free Electrochemical Aptasensor for Carcino-embryonic Antigen Based on Ternary Nanocomposite of Gold Nanoparticles, Hemin and Graphene;
2015. Available from: 10.1002/elan.201400524.

82. Verberne CJ, Wiggers T, Vermeulen KM, de Jong KP. Detection of recurrences during follow-up after liver surgery for colorectal metastases: both carcinoembryonic antigen (CEA) and imaging are important. Ann Surg Oncol. 2013;20(2):457-63. PMID: 22948771. Available from: 10.1245/s10434-012-2629-3.

83. Verberne CJ, Zhan Z, van den Heuvel E, Grossmann I, Doornbos PM, Havenga $\mathrm{K}$, et al. Intensified follow-up in colorectal cancer patients using frequent Carcino-Embryonic Antigen (CEA) measurements and CEA-triggered imaging: results of the randomized trial. Eur J Surg Oncol. 2015;41(9):1188-96. PMID: 26184850. Available from: 10.1016/j.ejso.2015.06.008.

84. Liu Z, Wang Y, Guo Y, Dong C. Label-free Electrochemical Aptasensor for Carcino-embryonic Antigen Based on Ternary Nanocomposite of Gold Nanoparticles, Hemin and Graphene. Electroanalysis. 2015;28(5):1023-1028. Available from: 10. 1002/elan.201500593.

85. Sato K, Nakate H, Sogabe S, Kohno H, Maeda K, Konno M, et al. Automated latex photometric immunoassay (Ipia) for determination of carcino embryonic antigen (cea). In: Clinical Chemistry . vol. 33. Washington, DC 20037-1526: Amer Assoc Clinical Chemistry; 1987. p. 920-920.

86. Falcone F, Sabbatani S, Fini A, Turba E, Magri P, D'Ales A. Combination of tissue polypeptide antigen (TPA) and carcino embryonic antigen (CEA) in different types of cancer. Nucl Med Commun. 1985;6(5):299-304. PMID: 4034127. Available from: 10.1097/00006231-198505000-00008.

87. Loo FC, Ng SP, Wu CM, Kong SK. An aptasensor using DNA aptamer and white light common-path SPR spectral interferometry to detect cytochrome-c for anti-cancer drug screening. Sens Actuators B Chem. 2014;198:416-23. Available from: 10.1016/j.snb.2014.03.077.

88. Lavrik IN. Systems Biology of Apoptosis. New York: Springer; 2012.

89. Yuan B, Zhou Y, Guo Q, Wang K, Yang X, Meng X, et al. A signal-on split aptasensor for highly sensitive and specific detection of tumor cells based on FRET. Chem Commun (Camb) 2016;52(8):1590-3. PMID: 26661391. Available from: 10.1039/ C5CC08060F

90. Zamay GS, Zamay TN, Kolovskii VA, Shabanov AV, Glazyrin YE, Veprintsev DV, et al. Electrochemical aptasensor for lung cancer-related protein detection in crude blood plasma samples. Sci Rep. 2016;6(1):34350. PMID: 27694916. Available from: $10.1038 /$ srep34350.

91. Hashemian Z, Khayamian T, Saraji M, Shirani MP. Aptasensor based on fluorescence resonance energy transfer for the analysis of adenosine in urine samples of lung cancer patients. Biosens Bioelectron. 2016;79:334-40. PMID: 26722763. Available from: 10.1016/j.bios.2015.12.028.

92. Qureshi A, Gurbuz Y, Niazi JH. Label-free capacitance based aptasensor platform for the detection of HER2/ErbB2 cancer biomarker in serum. Sens Actuators B Chem. 2015;220:114551. Available from: 10.1016/j.snb.2015.06.094.

93. Hu Y, Li L, Guo L. The sandwich-type aptasensor based on gold nanoparticles/DNA/magnetic beads for detection of cancer biomarker protein AGR2. Sens Actuators B Chem. 2015;209:846-52. Available from: 10.1016/j.snb.2014.12.068.

94. Chen X, Pan Y, Liu H, Bai X, Wang N, Zhang B. Label-free detection of liver cancer cells by aptamer-based microcantilever biosensor. Biosens Bioelectron. 2016;79:353-8. PMID: 26735868. Available from: 10.1016/j.bios.2015.12.060. 